Article

\title{
Ammonium Sorption from Landfill Leachates Using Natural and Modified Zeolites: Pre-Tests for a Novel Application of the Ion Exchanger Loop Stripping Process
}

\author{
Daniel Vollprecht ${ }^{1, *}$ (D) Sabrina Frühauf ${ }^{1}$, Kristina Stocker ${ }^{2}$ and Markus Ellersdorfer ${ }^{3}$ (D) \\ 1 Montanuniversität Leoben, Chair of Waste Processing Technology and Waste Management, \\ Franz-Josef-Str. 18, 8700 Leoben, Austria \\ 2 Montanuniversität Leoben, Chair of Resource Mineralogy, Peter-Tunner-Str. 5, 8700 Leoben, Austria \\ 3 Montanuniversität Leoben, Chair for Process Technology and Industrial Environmental Protection, \\ Franz-Josef-Str. 18, 8700 Leoben, Austria \\ * Correspondence: daniel.vollprecht@unileoben.ac.at; Tel.: +43-3842-402-5110
}

Received: 11 July 2019; Accepted: 29 July 2019; Published: 31 July 2019

\begin{abstract}
Ammonium $\left(\mathrm{NH}_{4}{ }^{+}\right)$is a main constituent of landfill leachates (50-2200 mg L$\left.{ }^{-1}\right)$ which has to be removed prior to indirect $\left(<200 \mathrm{mg} \mathrm{L}^{-1}\right)$ or direct discharge $\left(<10 \mathrm{mg} \mathrm{L}^{-1}\right)$ during landfill operation and aftercare, i.e., for more than 100 years after the end of waste disposal. In this study, lab-scale experiments regarding the sorption of $\mathrm{NH}_{4}{ }^{+}$from landfill leachates using natural and modified clinoptilolite $\left.\left(\mathrm{Ca}_{0.5}, \mathrm{Na}, \mathrm{K}\right)_{6}\left(\mathrm{Al}_{6} \mathrm{Si}_{30}\right) \mathrm{O}_{72} \cdot 20 \mathrm{H}_{2} \mathrm{O}\right)$ were conducted to assess the applicability of the innovative ion exchanger loop stripping (ILS) process for ammonium recovery. Samples of $20 \mathrm{~g}$ clinoptilolite after different pre-treatments (Ca loading, Na loading, natural loading) were shaken with $500 \mathrm{~mL}$ of each leachate from ten Austrian landfills $\left(75 \mathrm{mg} \mathrm{L}^{-1}<\mathrm{c}\left(\mathrm{NH}_{4}{ }^{+}\right)<2805 \mathrm{mg} \mathrm{L}^{-1}\right.$; $7.7<\mathrm{pH}<8.7)$ for $24 \mathrm{~h}$. Between $13 \%$ and $61 \%$ of the dissolved $\mathrm{NH}_{4}{ }^{+}$was adsorbed to the clinoptilolite, which remained stable during the experiment. In summary, our study indicates that the ILS process is highly promising with respect to $\mathrm{NH}_{4}{ }^{+}$recovery from landfill leachates, but further research is needed to reach threshold values for direct discharge.
\end{abstract}

Keywords: clinoptilolite; landfill aftercare; nitrogen recovery; ILS process

\section{Introduction}

Ammonium $\left(\mathrm{NH}_{4}{ }^{+}\right)$is a main constituent of leachates from municipal solid waste (MSW) landfills (50-2200 $\mathrm{mg} \mathrm{L}^{-1}$ ) [1]. It is formed in the landfill from MSW (which has an average nitrogen content of $0.67 \mathrm{wt} . \%$ dry matter [2]) by the microbial decomposition of proteins (ammonification) [3], which are present in organic waste or sewage sludge [4].

In 2004, landfilling of untreated MSW was prohibited in Austria [5]. However, the MSW which was landfilled prior to 2004 still releases 1.4 billion liters of leachate per year [6], which corresponds to $1134 \mathrm{ta}^{-1} \mathrm{NH}_{4}{ }^{+}$assuming an $\mathrm{NH}_{4}{ }^{+}$concentration of $800 \mathrm{mg} \mathrm{L}^{-1}$. This corresponds to more than $10 \%$ of the nitrogen demand of the industry in Austria, which uses $\mathrm{NH}_{4}{ }^{+}$for off-gas cleaning $\left(\mathrm{NO}_{\mathrm{x}}\right.$ reduction) [7].

About $90 \%$ of the total nitrogen in landfill leachate is present as $\mathrm{NH}_{4}{ }^{+}$[4]. $\mathrm{NO}_{3}{ }^{-}$formation (nitrification) is limited due to a lack of oxygen in the methanogenetic phase of landfills [4]. Therefore, $\mathrm{NH}_{4}{ }^{+}$concentration in the leachate can only decrease via leaching [8]. In the first two to five years of a landfill, $\mathrm{NH}_{4}{ }^{+}$concentrations in the leachate are predicted to increase and remain constant afterwards [9]. Over longer time scales, $\mathrm{NH}_{4}{ }^{+}$concentrations in leachate decrease [10], but residual 
concentrations may be found even 500 years after disposal [9]. A qualitative model of the evolution of landfill leachate and gas composition [1] has been adapted to the Austrian situation, i.e., landfill ban for untreated MSW in 2004, and to recent unpublished data indicating a decrease in methane $\left(\mathrm{CH}_{4}\right)$ content in landfill gas to 8-12 vol.\% (Figure 1).

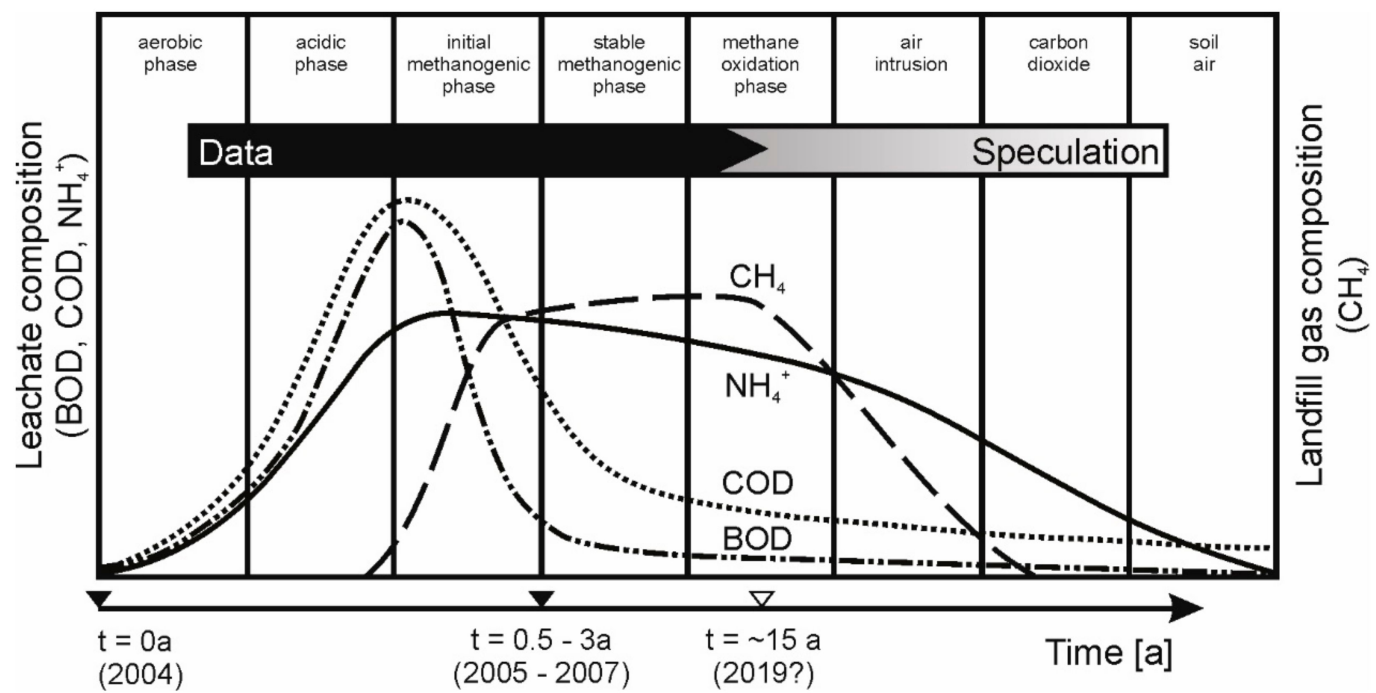

Figure 1. Evolution of landfill leachate and gas composition (modified from [1]).

According to Austrian legislation, $\mathrm{NH}_{4}{ }^{+}$has to be removed from landfill leachates prior to indirect $\left(<200 \mathrm{mg} \mathrm{L}^{-1}\right.$, in the case of unprotected cement-bound materials in public sewage systems $<50 \mathrm{mg} \mathrm{L}^{-1}$ ) or direct discharge $\left(<10 \mathrm{mg} \mathrm{L}^{-1}\right)$ [11]. For this purpose, landfills have to run leachate treatment plants during the aftercare period. Current legislation requires the formation of provisions for 40 years of aftercare for landfills containing biodegradable waste [12]. However, considering that landfill after care will be required for more than 100 years [9,13], these provisions will not be sufficient.

Currently applied microbiological methods for landfill leachate treatment convert $\mathrm{NH}_{4}{ }^{+}$to nitrate $\left(\mathrm{NO}_{3}{ }^{-}\right.$, nitrification) and further to nitrogen $\left(\mathrm{N}_{2}\right)$ or nitric oxides $\left(\mathrm{NO}_{\mathrm{x}}\right)$ (denitrification) [6]. Instead of an expensive microbial degradation, $\mathrm{NH}_{4}{ }^{+}$may also be recovered and utilized (for instance as a denitrification agent in the selective noncatalytic reduction (SNCR) of exhaust gases [14]).

Natural zeolites are hydrous framework aluminosilicates which are frequently used as sorbents for water and wastewater treatment [15]. Synthetic zeolites and their nanocrystalline precursor phases can also be used [16,17], but natural zeolites are often preferred in industrial applications due to their lower costs [18]. The crystal structure of clinoptilolite $\left.\left(\mathrm{Ca}_{0.5}, \mathrm{Na}, \mathrm{K}\right)_{6}\left(\mathrm{Al}_{6} \mathrm{Si}_{30}\right) \mathrm{O}_{72} \cdot 20 \mathrm{H}_{2} \mathrm{O}\right)$ is characterized by channels [19] which easily host $\mathrm{NH}_{4}{ }^{+}$ions. Consequently, clinoptilolite has already been used to remove $\mathrm{NH}_{4}{ }^{+}$from landfill leachates in batch column studies in which the effects of $\mathrm{pH}$, flow rate, $\mathrm{NH}_{4}{ }^{+}$concentration and competitive cations on the removal efficiency were also investigated [20]. For landfill leachate treatment, the competition of $\mathrm{NH}_{4}{ }^{+}$with other ions (e.g., $\mathrm{K}^{+}$) plays an important role [21].

The ion exchanger loop stripping (ILS) process combines ion exchange on clinoptilolite with the simultaneous air-stripping of ammonia [22] and has been successfully applied for the recovery of $\mathrm{NH}_{4}{ }^{+}$ from the excess water of sewage plants [23]. First process optimization has already been achieved by $\mathrm{NaOH}$ and $\mathrm{NaCl}$ pre-treatment of clinoptilolite [24]. $\mathrm{NaOH}$ treatment removes $\mathrm{Si}$ and preserves $\mathrm{Al}$ in the clinoptilolite structure which increases the number of acid adsorptive sites [25].

The main aim of this work is to test the ILS treatment for $\mathrm{NH}_{4}{ }^{+}$recovery from landfill leachates. The working hypothesis is that $\mathrm{NH}_{4}{ }^{+}$can be recovered from landfill leachates by sorption to clinoptilolite. This hypothesis is a prerequisite for the final scope of the work, as efficient removal is a crucial step to avoid material losses in the intended nitrogen cycle. The principal conclusions from our work will 
help to combine landfill aftercare with $\mathrm{NH}_{4}{ }^{+}$recycling, which corresponds to the concept of enhanced landfill mining [26].

We investigated the applicability of a natural zeolite from Slovakia for $\mathrm{NH}_{4}{ }^{+}$removal from a wide range of different Austrian landfill leachates, which has not been presented elsewhere. Another important novelty is the use of a coarser grain size, which is necessary for column operation in the ILS process in which ammonia is recovered from the zeolite. This connection of landfill leachate treatment or landfill aftercare with the idea of recycling nitrogen back to the industry represents the originality of this work.

\section{Materials and Methods}

\subsection{Materials}

A zeolite product specifically tailored for our purposes (particle size: 1-2.5 mm, >80 wt.\% clinoptilolite) from a Slovakian deposit was used for this study. The exact stoichiometry is $\left(\mathrm{Na}_{0.08} \mathrm{~K}_{0.43} \mathrm{Ca}_{1.64} \mathrm{Mg}_{0.14}\right)\left(\mathrm{Fe}^{3+}{ }_{0.06} \mathrm{Al}_{5.91} \mathrm{Si}_{30.51}\right) \mathrm{O}_{72} \cdot 25 \mathrm{H}_{2} \mathrm{O}$.

Leachate samples $(n=10)$ from Austrian landfills were provided by the respective landfill owners. Seven samples originate from mass waste landfills (an Austrian landfill class which mainly comprises residues of mechanical biological waste treatment), 1 sample is a concentrate from a leachate treatment plant of a residual waste landfill (currently mostly used for residues of thermal processes) and 2 samples are from landfills with compartments of either class.

\subsection{Methods}

Natural zeolites were treated for $24 \mathrm{~h}$ in packed-bed columns with $0.5 \mathrm{~mol} \mathrm{~L}^{-1} \mathrm{CaCl}_{2}$ and $32 \%$ $\mathrm{NaOH}$ to obtain $\mathrm{Ca}$ - and Na-treated zeolite, respectively. The treated samples were flushed with deionized water, dried over night at $105^{\circ} \mathrm{C}$ and stored in a hermetically sealed plastic container until further application.

The zeolite products with different cation loading and the used zeolites after treatment of landfill leachates were characterized by X-ray diffraction (XRD, PANalytical X'Pert Pro, Co K $\alpha, \lambda=1.7902 \mathrm{~nm}$, Institute of Applied Geosciences of Graz University of Technology, Graz, Austria). XRD patterns were evaluated with the software package X'Pert HighScore Plus with its attached databases.

Landfill leachates were characterized optically for solid constituents. $\mathrm{pH}$ was determined prior to the experiments (WTW inoLab $\mathrm{pH} / \mathrm{ION} / \mathrm{Cond} 750$ ). $\mathrm{NH}_{4}{ }^{+}$concentrations were determined without filtration before and after the experiments by the Kjeldahl method [27] using boric acid $\left(\mathrm{H}_{3} \mathrm{BO}_{3}, 4\right.$ vol.\%) and hydrochloric acid $\left(\mathrm{HCl}, 0.01 / 1 \mathrm{~mol} \mathrm{~L}^{-1}\right)$ /Tashiro's indicator for titration. Measuring accuracy accounted for $0.6 \%$.

$\mathrm{NH}_{4}{ }^{+}$exchange isotherms were determined in batch experiments with ammonium sulphate $\left(\left(\mathrm{NH}_{4}\right)_{2} \mathrm{SO}_{4}\right)$ solutions (Chair of Process Technology and Industrial Environmental Protection, Montanuniversität Leoben, Leoben, Austria). $\left(\mathrm{NH}_{4}\right)_{2} \mathrm{SO}_{4}$ solutions $(500 \mathrm{~mL})$ (concentration range: 500-5000 $\mathrm{mg} \mathrm{NH}_{4}{ }^{+} \mathrm{L}^{-1}$ ) were contacted with $20 \mathrm{~g}$ of treated (Ca loading and $\mathrm{Na}$ loading) and untreated (natural loading) zeolite, which were placed in cotton bags in an overhead shaker for $24 \mathrm{~h}$ at $20^{\circ} \mathrm{C}$. After the experiments, zeolite samples were dried at $105^{\circ} \mathrm{C}$ and sealed in plastic containers for subsequent XRD analyses. Liquid samples were taken before and after ion exchange. The difference in $\mathrm{NH}_{4}{ }^{+}$ concentration of the initial and final solution represents the amount of exchanged $\mathrm{NH}_{4}{ }^{+}$and therefore the effective cation exchange capacity (CEC) for different equilibrium concentrations. Exchange isotherms were obtained by fitting the experimental data to the Langmuir adsorption equation using nonlinear regression.

Sorption experiments with landfill leachates using natural and treated zeolites were conducted using the same batch system and experimental conditions as for isotherm determination. Zeolite removal rates for ammonium were calculated by dividing the difference in the concentrations of the leachates before and after $24 \mathrm{~h}$ of sorption by the initial $\mathrm{NH}_{4}{ }^{+}$concentration of the investigated landfill 
leachate. The equilibrium sorption was calculated by dividing the amount of recovered $\mathrm{NH}_{4}{ }^{+}$by the amount of used zeolite.

\section{Results}

\subsection{Zeolite Characterization}

XRD analyses confirm the presence of clinoptilolite as the main mineral phase in the samples. Accessory phases include mica (e.g., biotite $\left.\left(\mathrm{K}\left(\mathrm{Mg}, \mathrm{Fe}^{2+}, \mathrm{Mn}^{2+}\right)_{3}\left((\mathrm{OH}, \mathrm{F})_{2} \mid \mathrm{AlSi}_{3} \mathrm{O}_{10}\right)\right)\right)$, quartz $\left(\mathrm{SiO}_{2}\right)$, plagioclase $\left(\left(\mathrm{Na}_{x}, \mathrm{Ca}_{1-\mathrm{x}}\right) \mathrm{Al}_{2-\mathrm{x}} \mathrm{Si}_{2+\mathrm{x}} \mathrm{O}_{8}\right)$ and probably opal-C $\left(\mathrm{SiO}_{2} \cdot \mathrm{nH}_{2} \mathrm{O}\right)$. Minor differences regarding the accessory minerals (grey ranges in Figure 2) are found between samples after different pre-treatment, but they are more likely to be due to the heterogeneity of the material than due to the pre-treatment. The different cation loading has no significant impact on the location and shape of the clinoptilolite peaks.

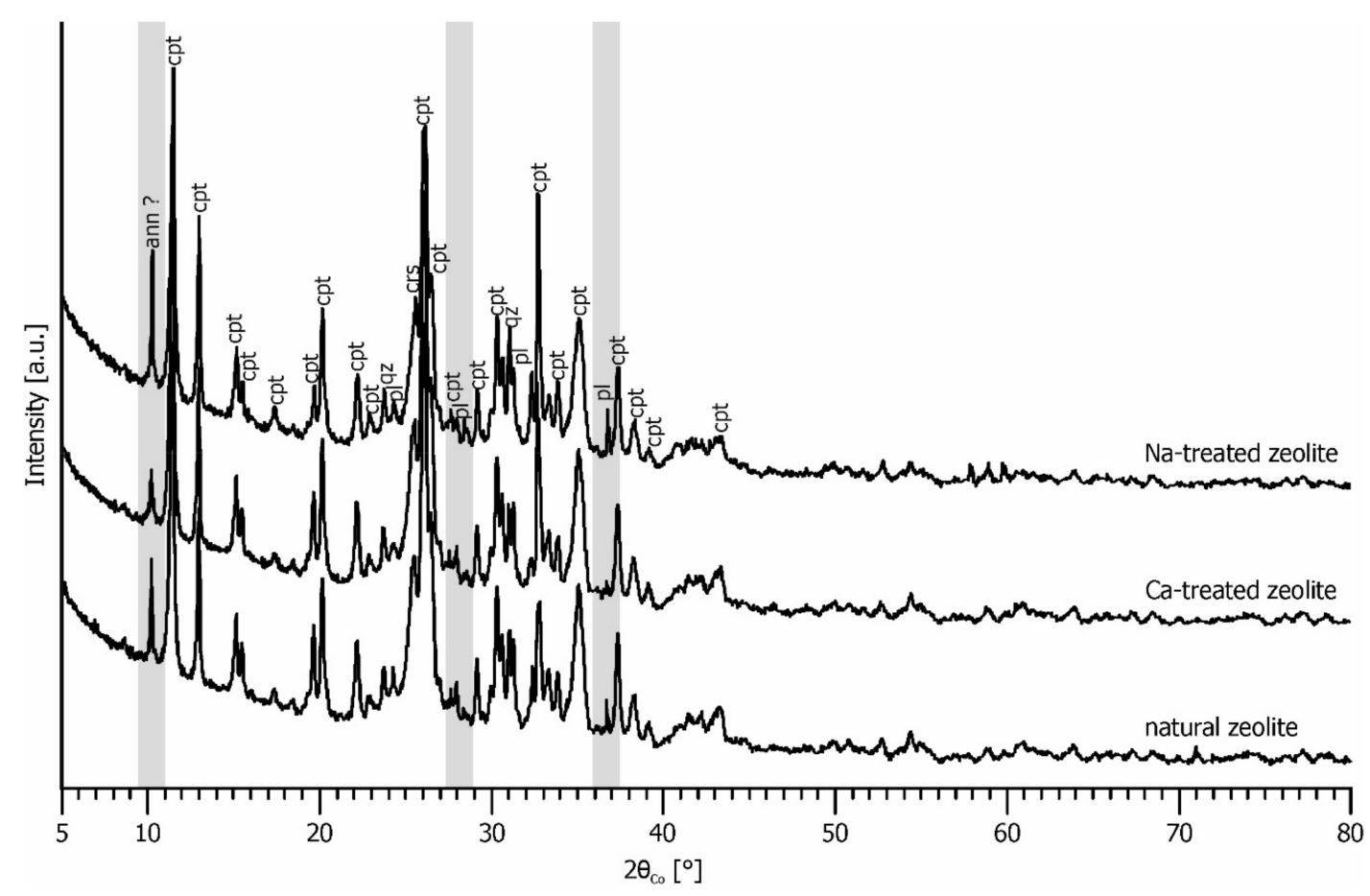

Figure 2. X-ray diffraction (XRD) patterns of zeolites with different cation loading (ann: annite, cpt: clinoptilolite, pl: plagioclase, qz: quartz).

\subsection{Leachate Characterization}

The investigated landfill leachates are characterized by neutral to slightly alkaline $\mathrm{pH}(7.0-8.7)$ (Table 1). This range is typical for the methanogenetic phases of MSW bioreactor landfills [1]. The investigated samples are characterized by a yellow/brown color and $\mathrm{NH}_{4}{ }^{+}$concentrations between 8-2805 $\mathrm{mg} \mathrm{L}^{-1}$. The sample with an $\mathrm{NH}_{4}{ }^{+}$concentration below $100 \mathrm{mg} \mathrm{L}^{-1}$ is characterized by a yellowish to light brown color, whereas samples with $\mathrm{NH}_{4}{ }^{+}$concentrations above $100 \mathrm{mg} \mathrm{L}^{-1}$ are darker brown to black. The presence or absence of solid particles does not correlate with the $\mathrm{NH}_{4}{ }^{+}$ concentration, although no filtration was conducted prior to Kjeldahl analyses, which suggests that $\mathrm{NH}_{4}{ }^{+}$is preferentially dissolved and not adsorbed to particles. 
Table 1. Landfill leachates (LL) used for $\mathrm{NH}_{4}{ }^{+}$ion exchange experiments, their corresponding landfill class, $\mathrm{pH}$ value, color/transparency, presence of solid particles and initial $\mathrm{NH}_{4}{ }^{+}$concentrations. MW: mass waste landfill, RW: residual waste landfill.

\begin{tabular}{|c|c|c|c|c|c|}
\hline Sample & Landfill Class & $\mathrm{pH}$ & Color/Transparency & Solid Particles & $\begin{array}{c}\mathrm{NH}_{4}^{+} \\
\text {Concentration } \\
\left(\mathrm{mg} \mathrm{L}^{-1}\right)\end{array}$ \\
\hline LL 1 & MW & 7.7 & Dark brown to black & None & 350 \\
\hline LL 2 & MW & 8.2 & Dark brown to black & None & 2805 \\
\hline LL 3 & MW & 8.7 & Dark brown to black & None & 645 \\
\hline LL 4 & MW & 8.5 & Brown & None & 945 \\
\hline $\operatorname{LL} 5^{1}$ & RW & 8.3 & $\begin{array}{c}\text { Grey to } \\
\text { yellowish/cloudy }\end{array}$ & $\begin{array}{l}\text { Transparent floating } \\
\text { particles, black particles } \\
(0.063-0.2 \mathrm{~mm})\end{array}$ & 1037 \\
\hline LL 6 & MW & 8.3 & Orange to brown & $\begin{array}{l}\text { Black particles } \\
(0.063-2.0 \mathrm{~mm}) \\
\end{array}$ & 523 \\
\hline LL 7 & MW & 8.6 & $\begin{array}{l}\text { Orange to dark } \\
\text { brown }\end{array}$ & $\begin{array}{c}\text { Transparent floating } \\
\text { particles, black particles } \\
(0.063-2.0 \mathrm{~mm})\end{array}$ & 503 \\
\hline LL 8 & MW & 7.7 & (Dark) brown & $\begin{array}{l}\text { Black flaky particles } \\
\quad(2.0-6.3 \mathrm{~mm})\end{array}$ & 153 \\
\hline LL 9 & MW/RW & 8.3 & Dark brown to black & $\begin{array}{l}\text { Black flaky particles } \\
(2.0-6.3 \mathrm{~mm})\end{array}$ & 1073 \\
\hline LL 10 & MW & 8.2 & $\begin{array}{c}\text { Light } \\
\text { brown/transparent }\end{array}$ & None & 75 \\
\hline
\end{tabular}

\subsection{Sorption Efficiency}

Adsorption isotherms indicate an order of $\mathrm{NH}_{4}{ }^{+}$sorption capacity depending on the cation loading: Na loading > Ca loading > natural loading (Figure 3). Up to $20-25 \mathrm{mg} \mathrm{NH}_{4}^{+} \mathrm{g}^{-1}$ zeolite can be sorbed at the inner and outer surfaces. Considering the stoichiometry of the clinoptilolite used in this study, $\left(\mathrm{Na}_{0.08} \mathrm{~K}_{0.43} \mathrm{Ca}_{1.64} \mathrm{Mg}_{0.14}\right)\left(\mathrm{Fe}^{3+}{ }_{0.06} \mathrm{Al}_{5.91} \mathrm{Si}_{30.51}\right) \mathrm{O}_{72} \cdot 25 \mathrm{H}_{2} \mathrm{O}, 4.07 \mathrm{~mol}$ of $\mathrm{NH}_{4}{ }^{+}$, i.e., $73 \mathrm{~g}$, might be adsorbed to $1 \mathrm{~mol}$ of clinoptilolite in case of complete occupancy of the crystallographic $\mathrm{A}$ site $\left(\mathrm{Ca}_{0.5}, \mathrm{Na}, \mathrm{K}, \mathrm{Mg}\right)$ by $\mathrm{NH}_{4}{ }^{+}$. This corresponds to a loading of $28 \mathrm{mg} \mathrm{NH}_{4}{ }^{+}$per g zeolite (assuming a molecular weight for $\mathrm{NH}_{4}{ }^{+}$-clinoptilolite of $2622 \mathrm{~g} \mathrm{~mol}^{-1}$ ). Experimental results indicate that in equilibrium with $\mathrm{Na}$ and $\mathrm{Ca}$, about two thirds of the sites are occupied by $\mathrm{NH}_{4}{ }^{+}$, whereas in equilibrium with $\mathrm{Na}$ only, $\mathrm{NH}_{4}{ }^{+}$occupies up to $80 \%$ of the crystallographic A sites.

The $\mathrm{NH}_{4}{ }^{+}$adsorption data on natural and $\mathrm{Na} / \mathrm{Ca}$ treated zeolites are best fitted by the Langmuir isotherm $\left(\mathrm{q}_{\mathrm{e}}=\mathrm{q}_{\mathrm{m}} \times \mathrm{K}_{\mathrm{L}} \times \mathrm{C}_{\mathrm{e}} /\left(1+\mathrm{K}_{\mathrm{L}} \times \mathrm{C}_{\mathrm{e}}\right)\right)$ indicating a specifically limited adsorption capacity with a monolayer surface coverage. Results $\left(\mathrm{q}_{\mathrm{e}}\left(\mathrm{mg} \mathrm{g}^{-1}\right)=\right.$ equilibrium loading; $\mathrm{C}_{\mathrm{e}}\left(\mathrm{mg} \mathrm{L}^{-1}\right)=$ equilibrium concentration) for Langmuir fitting are $\left(\mathrm{qm}_{\mathrm{m}}\left(\mathrm{mg} \mathrm{g}^{-1}\right) ; \mathrm{K}_{\mathrm{L}}\left(\mathrm{L} \mathrm{mg}^{-1}\right)=\right.$ Langmuir constant; $\mathrm{R}^{2}(-)=$ statistical variance): natural zeolite (19.839 $\left.\pm 1.092 ; 0.0028 \pm 6.28 \times 10^{-4} ; 0.947\right)$, Ca-loaded zeolite $(21.154 \pm 0.916$; $\left.0.0031 \pm 5.57 \times 10^{-4} ; 0.965\right)$ and Na-loaded zeolite $\left(25.512 \pm 3.824 ; 0.0020 \pm 1.02 \times 10^{-3} ; 0.7994\right)$.

Equilibrium loadings for landfill leachates are significantly below the sorption isotherms which were obtained by ideal solutions (Figure 3). This demonstrates that competition between different ions occurs in landfill leachates, which is not the case for ideal solutions. Also for landfill leachates, Na-treated zeolite shows better performance than Ca-treated and natural zeolite. 


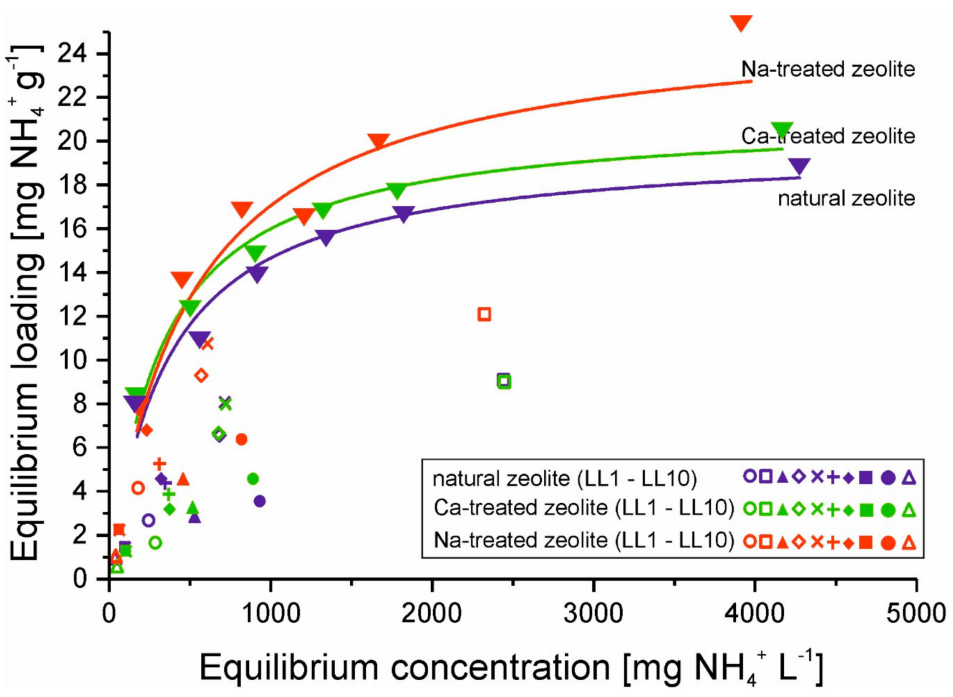

Figure 3. Adsorption isotherms (lines and triangles) of zeolites with different cation loading (blue: natural loading, green: Ca loading, red: Na loading) and equilibrium loadings and concentrations from experiments with landfill leachates (spots).

Removal rates for $\mathrm{NH}_{4}{ }^{+}$from landfill leachates are in the range of $13-52 \%$ for natural zeolite, 13-33\% for Ca-treated zeolite and 17-61\% for Na-treated zeolite (Table 2, Figure 4). For each leachate the removal rate using Na-treated zeolite was higher than for Ca-treated zeolite and natural zeolite. For $70 \%$ of the leachates, the removal rate using natural zeolite was higher than for Ca-treated zeolite, but overall this difference is not significant. In summary, this means that $\mathrm{Na}$ treatment of the used zeolite significantly increased the efficiency of $\mathrm{NH}_{4}{ }^{+}$removal, whereas $\mathrm{Ca}$ treatment did not have a significant impact. Comparing the removal rate with the initial $\mathrm{NH}_{4}{ }^{+}$concentration shows that the two highest removal rates were obtained for landfill leachates (LL) 8 and 10, which are the samples with the lowest initial $\mathrm{NH}_{4+}$ concentrations $\left(153 \mathrm{mg} \mathrm{L}^{-1}\right.$ and $\left.75 \mathrm{mg} \mathrm{L}^{-1}\right)$. Consequently, the equilibrium sorption of $\mathrm{NH}_{4}{ }^{+}$to the used zeolite was lowest for these samples (between $0.6-2.3 \mathrm{mg} \mathrm{L}^{-1}$ ). The highest equilibrium sorption is observed for LL $2\left(9.0-12.1 \mathrm{mg} \mathrm{g}^{-1}\right)$, followed by LL $5\left(8.0-10.8 \mathrm{mg} \mathrm{g}^{-1}\right)$.

Table 2. Landfill leachates (LL) used for $\mathrm{NH}_{4}{ }^{+}$ion exchange experiments, their initial concentration, equilibrium concentration, equilibrium loading and the corresponding removal rates using differently pre-treated zeolites.

\begin{tabular}{|c|c|c|c|c|c|c|c|c|c|c|}
\hline \multirow[t]{2}{*}{ Sample } & \multirow{2}{*}{$\begin{array}{c}\text { Initial } \mathrm{NH}_{4}^{+} \\
\text {Concentration } \\
\left(\mathrm{mg} \mathrm{L}^{-1}\right) / \text { Cation Loading }\end{array}$} & \multicolumn{3}{|c|}{$\begin{array}{c}\text { Equilibrium } \mathrm{NH}_{4}^{+} \\
\text {Concentration }\left(\mathrm{mg} \mathrm{L}^{-1}\right)\end{array}$} & \multicolumn{3}{|c|}{$\begin{array}{l}\text { Equilibrium } \mathrm{NH}_{4}{ }^{+} \\
\text {Loading }\left(\mathrm{mg} \mathrm{g}^{-1}\right)\end{array}$} & \multicolumn{3}{|c|}{ Removal Rate (\%) } \\
\hline & & Natural & $\mathrm{Ca}$ & $\mathrm{Na}$ & Natural & $\mathrm{Ca}$ & $\mathrm{Na}$ & Natural & $\mathrm{Ca}$ & $\mathrm{Na}$ \\
\hline LL 1 & 350 & 244 & 283 & 180 & 2.65 & 1.67 & 4.24 & 30.4 & 19.1 & 48.5 \\
\hline LL 2 & 2805 & 2440 & 2444 & 2323 & 9.13 & 9.02 & 12.06 & 13.0 & 12.9 & 17.2 \\
\hline LL 3 & 645 & 528 & 514 & 460 & 2.93 & 3.27 & 4.62 & 18.2 & 20.3 & 28.7 \\
\hline LL 4 & 945 & 681 & 677 & 573 & 6.59 & 6.71 & 9.30 & 27.9 & 28.4 & 39.4 \\
\hline LL 5 & 1037 & 713 & 717 & 604 & 8.12 & 8.00 & 10.82 & 31.3 & 30.9 & 41.7 \\
\hline LL 6 & 523 & 347 & 368 & 311 & 4.40 & 3.89 & 5.30 & 33.6 & 29.7 & 40.5 \\
\hline LL 7 & 503 & 320 & 374 & 232 & 4.58 & 3.22 & 6.77 & 36.4 & 25.6 & 53.9 \\
\hline LL 8 & 153 & 95 & 103 & 60 & 1.47 & 1.26 & 2.34 & 38.2 & 32.9 & 61.2 \\
\hline LL 9 & 1073 & 929 & 888 & 816 & 3.61 & 4.62 & 6.42 & 13.4 & 17.2 & 24.0 \\
\hline LL 10 & 75 & 36 & 51 & 32 & 0.97 & 0.59 & 1.08 & 51.8 & 31.3 & 57.8 \\
\hline
\end{tabular}




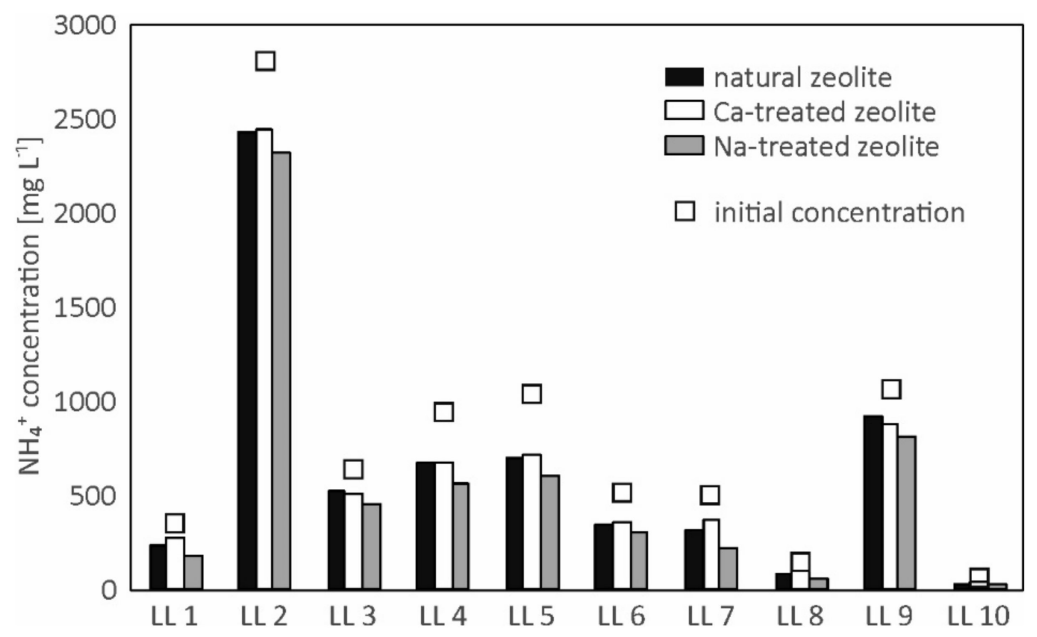

Figure 4. Initial ammonium concentrations (squares) and remaining concentrations after treatment with differently treated zeolites (bars) in different landfill leachates (LL).

\subsection{Zeolite Stability}

XRD patterns of spent zeolite samples reveal no changes in the intensity, shape and location of clinoptilolite peaks, which suggests that clinoptilolite does not dissolve in the course of the experiments (Figure 5). No additional phases are present after the experiments, i.e., no precipitation of minerals from the landfill leachate was detectable. Minor changes in the intensities of the peaks of annite and plagioclase (grey ranges in Figure 5) are again due to the heterogeneity of the natural material and not due to the changes during the experiment.

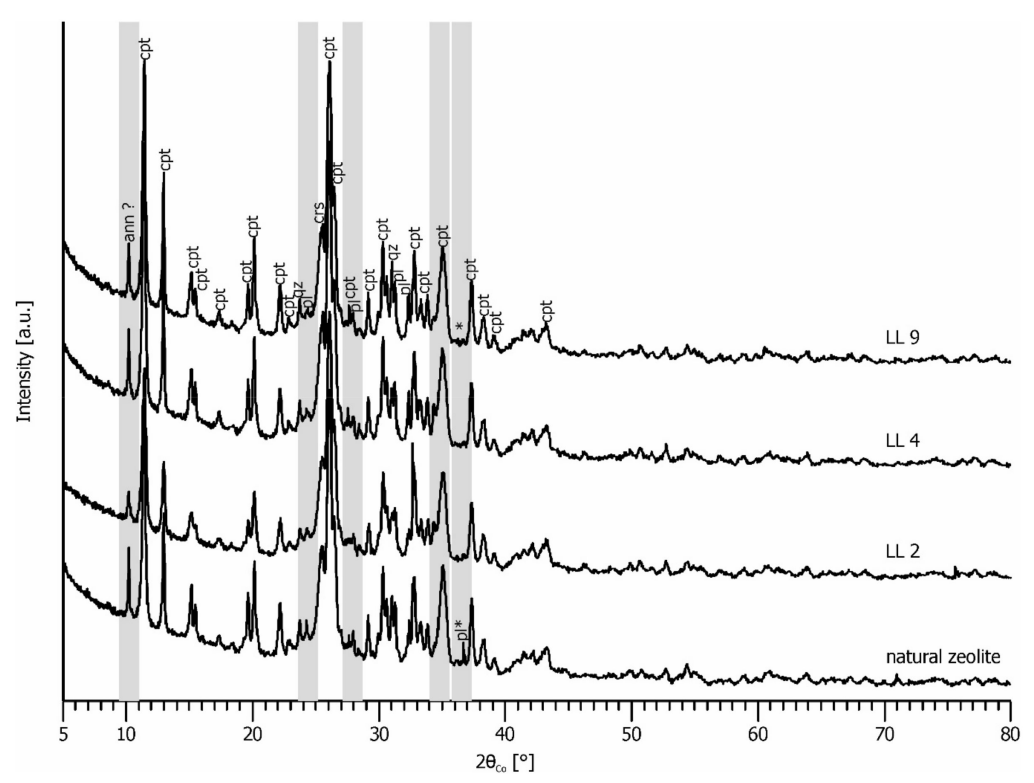

Figure 5. XRD patterns of untreated zeolite before and after reaction with landfill leachates.

\section{Discussion}

$\mathrm{NH}_{4}{ }^{+}$concentration in the investigated landfill leachates are in agreement with literature data [1]. The brown color is suggested to be due to humic substances which represent a significant group of organic compounds in landfills whose aromatic character, molecular weight and consequently whose color intensity increases with the age of the landfill due to humification [28]. This suggests that $\mathrm{NH}_{4}{ }^{+}$ is present in intensely colored landfill leachates as $\mathrm{NH}_{4}{ }^{+}$humate [29]. Adsorption isotherms were obtained for much higher dissolved $\mathrm{NH}_{4}{ }^{+}$concentrations (up to $4500 \mathrm{mg} \mathrm{L}^{-1}$ ) than in a previous 
study in which only up to $150 \mathrm{mg} \mathrm{L}^{-1} \mathrm{NH}_{4}{ }^{+}$were tested [28]. However, the shape of the isotherms suggest that the observed difference in final $\mathrm{NH}_{4}{ }^{+}$loads of the zeolites (about $10 \mathrm{mg} \mathrm{g}^{-1}$ in the previous study [30] and $20 \mathrm{mg} \mathrm{g}^{-1}$ for our study) are not due to different dissolved concentrations. A comparison of the chemical composition of the used clinoptilolites $[24,30]$ shows that our zeolite has a higher $\mathrm{K} / \mathrm{Ca}$ ratio which suggests that the lower average charge of the initially present cations allows for an easier exchange against $\mathrm{NH}_{4}{ }^{+}$.

$\mathrm{NH}_{4}{ }^{+}$removal rates in the present study range from $13-61 \%$ and are comparable to the values obtained for the Gördes clinoptilolite and a Turkish landfill leachate in the $\mathrm{pH}$ range of 7-8 (50-60\%) [20]. The lower removal rates $(<50 \%)$ obtained for some combinations of landfill leachates and zeolites in this study may derive from differences in the $\mathrm{K}_{2} \mathrm{O}$ content (5.0 wt. $\%$ vs. $2.83 \mathrm{wt} . \%$ ) and particle sizes (0.6-1.2 $\mathrm{mm}$ vs. $1-2.5 \mathrm{~mm}$ ) compared to the previous study [20]. Furthermore, the previous study shows that the sorption efficiency decreases with increasing $\mathrm{NH}_{4}{ }^{+}$concentration down to about $40 \%$ for $1500 \mathrm{mg} \mathrm{L}^{-1}$. This is in agreement with our observations, which revealed lower removal rates for leachate samples with higher initial ammonium concentrations.

\section{Conclusions}

In this study, natural clinoptilolite with three different cation loadings (Ca loading, Na loading and natural loading) was used to remove $\mathrm{NH}_{4}{ }^{+}$from 10 landfill leachates. The working hypothesis that $\mathrm{NH}_{4}{ }^{+}$can be removed from landfill leachates by sorption to clinoptilolite was generally confirmed. Removal rates are in the range of $13-52 \%$ for natural zeolite, $13-33 \%$ for Ca-treated zeolite and $17-61 \%$ for Na-treated zeolite. Na treatment enhanced the ammonium removal rate for each single leachate compared to Ca-treated zeolite and natural zeolite. Sorption efficiencies can be increased by using higher zeolite/liquid ratios to enhance the total ion exchange and therefore significantly increase the removable quantities of $\mathrm{NH}_{4}{ }^{+}$from landfill leachates. However, considering a removal rate of $40 \%$, more than $450 \mathrm{ta}^{-1} \mathrm{NH}_{4}{ }^{+}$might be removed from landfill leachates in Austria which still represents a significant share of the entire nitrogen demand for off-gas cleaning of the national industry. This potential might be exploited if the $\mathrm{NH}_{4}{ }^{+}$-loaded clinoptilolite is subjected to the second step of the ILS process, in which ammonia is recovered by stripping, which will be tested in the near future.

The main advantage of the solution proposed in this study is the possible integration into in situ enhanced landfill mining concepts, i.e. the transformation of waste into a resource by extraction of raw materials from landfills using natural water flow. Furthermore, this approach of in situ landfill mining has the advantage over ex situ landfill mining in that much smaller volumes of material need to be treated and natural extraction processes are used. The proposed method is therefore more economical as costs for sludge and concentrate treatment (which are required in state-of-the-art biological landfill leachate treatment plants) can be reduced. Further process optimization or other approaches of zeolite modification will additionally improve the performance and the feasibility of this concept.

Author Contributions: Conceptualization, M.E.; methodology, M.E.; investigation, S.F.; resources, M.E.; writing-original draft preparation, D.V.; writing-review and editing, M.E. and K.S.; visualization, K.S.; supervision, D.V.; project administration, M.E.; funding acquisition, M.E.

Funding: This research was funded by the Austrian Research Promotion Agency, grant number 864876.

Acknowledgments: The Authors thank Johann Raith and Roland Pomberger for co-supervision and Jan Lubensky for experimental support. Martin Dietzel, Graz University of Technology, is thanked for giving access to the XRD facilities.

Conflicts of Interest: The authors declare no conflict of interest.

\section{References}

1. Kjeldsen, P.; Barlaz, M.; Rooker, A.; Braun, A.; Ledin, A.; Christensen, T. Present and Long-Term Composition of MSW Landfill Leachate: A Review. Crit. Rev. Environ. Sci. Technol. 2002, 32, 297-336. [CrossRef]

2. Barlaz, M.; Ham, D.; Schaefer, D.; Isaacson, R. Methane production from municipal refuse: A review of enhancement techniques and microbial dynamics. Crit. Rev. Environ. Control 1990, 19, 557-584. [CrossRef] 
3. Christensen, T.; Kjeldsen, P.; Bjerg, P.; Jensen, D.; Christensen, J.; Baun, A.; Albrechtsen, H.J.; Heron, G. Review: Biogeochemistry of landfill leachate plumes. Appl. Geochem. 2001, 16, 659-718. [CrossRef]

4. Burton, S.; Watson-Craik, I. Ammonia and nitrogen fluxes in landfill sites: Applicability to sustainable landfilling. Waste Manag. Res. 1998, 16, 41-53. [CrossRef]

5. Bundesminster für Umwelt. Verordnung über die Ablagerung von Abfällen (Deponieverordnung); Bundesminister für Umwelt: Vienna, Austria, 1996.

6. Schachermayer, E.; Lampert, C. Aufkommen und Behandlung von Deponiesickerwasser-Bestandsaufnahme an ausgewählten österreichischen Deponien; Umweltbundesamt: Vienna, Austria, 2010.

7. Pesendorfer, S.; Ellersdorfer, M. Nutrient recovery and utilization potential from wastewater in Austria. Minisymposium Verfahrenstechnik 2019, 15, 115.

8. Robinson, H.A. Review of the Composition of Leachates from Domestic Wastes in Landfill Sites. In The Technical Aspects of Controlled Waste Management; Report for the UK Department of the Environment, Waste Science and Research; Aspinwall \& Company, Ltd.: London, UK, 1995.

9. Ehrig, H.J. Leachate Quality. In Sanitary Landfilling Process Technology and Environmental Impact; Academic Press: London, UK, 1989; pp. 213-229.

10. Andreottola, G.; Cannas, P.; Cossu, R. Overview on Landfill Leachate Quality; CISA Environmental Sanitary Engineering Centre: Caligary, Italy, 1990.

11. Bundesminister für Land- und Forstwirtschaft, Umwelt und Wasserwirtschaft. Verordnung über die Begrenzung von Sickerwasseremissionen aus Abfalldeponien (AEV Deponiesickerwasser); Bundesminister für Land- und Forstwirtschaft, Umwelt und Wasserwirtschaft: Vienna, Austria, 2003.

12. Bundesminister für Land- und Forstwirtschaft, Umwelt und Wasserwirtschaft. Verordnung über Deponien (Deponieverordnung 2008-DVO 2008); Bundesminister für Land- und Forstwirtschaft, Umwelt und Wasserwirtschaft: Vienna, Austria, 2008.

13. Laner, D.; Fellner, J.S. Ableitung standortspezifischer Nachsorgeentlassungskriterien: Fallstudien. Depo Tech 2012, 11, 539-544.

14. Hollauf, B. Ammonsulfat zur selektiven nicht-katalytischen Stickoxidreduktion von Zementwerksabgasen. Ph.D. Thesis, Montanuniversität Leoben, Leoben, Austria, 2010.

15. Wang, S.; Peng, Y. Review: Natural zeolites as effective adsorbents in water and wastewater treatment. Chem. Eng. J. 2010, 156, 11-24. [CrossRef]

16. Höllen, D.; Klammer, D.; Letofsky-Papst, I.; Dietzel, M. Hydrothermal Alteration of Diatomite for Removal of Aqueous $\mathrm{Cu}^{2+}, \mathrm{Pb}^{2+}$ and $\mathrm{Zn}^{2+}$. Mater. Sci. Eng. B 2012, 10, 523-533.

17. Höllen, D.; Klammer, D.; Letofsky-Papst, I.; Raab, G.; Dietzel, M. Synthesis of hierarchically structured materials: Microporous diatoms and nanoporous hydroxyaluminosilicate. Nanotechnol. Environ. Eng. 2016, 1, 1-9. [CrossRef]

18. Stocker, K.; Ellersdorfer, M.; Lehner, M.; Raith, J.R. Characterization and Utilization of Natural Zeolites in Technical Applications. Berg- und Hüttenmännische Monatshefte 2017, 162, 142-147. [CrossRef]

19. Akgül, M. Enhancement of the anionic dye adsorption capacity of clinoptiloliteby $\mathrm{Fe}^{3+}$ grafting. J. Hazard. Mater. 2014, 267, 1-8. [CrossRef] [PubMed]

20. Karadag, D.; Tok, S.; Akgul, E.; Turan, M.; Ozturk, M.; Demir, A. Ammonium removal from sanitary landfill leachate using natural Gördes clinoptilolite. J. Hazard. Mater. 2008, 153, 60-66. [CrossRef] [PubMed]

21. Vocciante, M.; De Folly D'Auris, A.; Finocchi, A.; Tagliabue, M.; Bellettato, M.; Ferrucci, A.; Reverberi, A.P.; Ferro, S. Adsorption of ammonium on clinoptilolite in presence of competing cations: Investigation on groundwater remediation. J. Clean. Prod. 2018, 198, 480-487. [CrossRef]

22. Ellersdorfer, M. The ion-exchanger-loop-stripping process: Ammonium recovery from sludge liquor using NaCl-treated clinoptilolite and simultaneous air stripping. Water Sci. Technol. 2018, 77, 695-705. [CrossRef] [PubMed]

23. Lubensky, J.; Ellersdorfer, M.; Stocker, K.; Lechleitner, A. Pilotversuche zum Recycling von Ammonium aus Trübwässern an einer Kläranlage. Recy DepoTech 2018, 14, 729-734.

24. Stocker, K.; Ellersdorfer, M.; Lechleitner, A.; Lubensky, J.; Raith, J.R. Impact of concentrated acid, base and salt pretreatments on the characteristics of natural clinoptilolite and its ammonium uptake from model solution and real effluents. Microporous Mesoporous Mat. 2019, 288, 109553. [CrossRef]

25. Castro De Souza, V.; Villarroel-Rocha, J.; Gomes De Araújo, M.J.; Sapag, K.; Pergher, S.B.C. Basic Treatment in Natural Clinoptilolite for Improvement of Physicochemical Properties. Minerals 2018, 8, 595. [CrossRef] 
26. Vollprecht, D.; Küppers, B.; Pomberger, R.; Machiels, L.; Bernardo, E.; Krook, J. Das EU Training Network for Resource Recovery Through Enhanced Landfill Mining (NEW-MINE). Recy DepoTech 2018, 14, 561-568.

27. Kjeldahl, J. Neue Methode zur Bestimmung des Stickstoffs in organischen Körpern. Zeitschrift für Analytische Chemie 1883, 22, 366-382. [CrossRef]

28. Kang, K.H.; Shin, H.; Park, H. Characterization of humic substances present in landfill leachates with different landfill ages and its implications. Water Res. 2002, 36, 4023-4032. [CrossRef]

29. Kirdy, T.; Veselov, A. Phytoprotective Effect of Ammonium Humate at High Copper Concentrations in the Environment. Biol. Bull. 2017, 44, 1284-1288. [CrossRef]

30. Wang, Y.F.; Lin, F.; Pang, W.Q. Ammonium exchange in aqueous solution using Chinese natural clinoptilolite and modified zeolite. J. Hazard. Mater. 2007, 142, 160-164. [CrossRef] [PubMed]

(C) 2019 by the authors. Licensee MDPI, Basel, Switzerland. This article is an open access article distributed under the terms and conditions of the Creative Commons Attribution (CC BY) license (http://creativecommons.org/licenses/by/4.0/). 